\title{
Effect of Heat Stress on Poultry Production and their Managemental Approaches
}

\author{
Ashish Ranjan ${ }^{1 *}$, Ranjana Sinha ${ }^{2}$, Indu Devi ${ }^{3}$, Abdul Rahim ${ }^{4}$ and Shiwani Tiwari ${ }^{5}$ \\ ${ }^{1}$ Division of Animal Genetics and Breeding, ICAR-NDRI, Karnal-132001, Haryana, India \\ ${ }^{2}$ Semen sexing in cattle, ICAR-NDRI, Karnal-132001, Haryana, India \\ ${ }^{3}$ CSWRI, Avikanagar, Rajsthan 304501, India \\ ${ }^{4}$ CSWRI, Garsa (Himachal Pradesh)-175141, India \\ ${ }^{5}$ Livestock Production and Management, COA, JNKVV, Jabalpur, \\ (Maghya Pradesh)-482004, India \\ *Corresponding author
}

\section{A B S T R A C T}

\section{Keywords \\ Broiler, Egg production, Heat stress, Poultry, Ventilation \\ Article Info \\ Accepted: \\ 12 January 2019 \\ Available Online: \\ 10 February 2019}

\begin{abstract}
Air temperature and relative humidity are two primary environmental factors in terms of THI that determining the heat stress level in livestock. Heat stress has detrimental effects on egg production, egg quality of laying hen and reduced growth rate in broiler production. Exposure of environmental stress during the growing period of broilers has been coupled with undesirable meat quality. Heat stress has adverse effects on behaviour, welfare and immunity of poultry and decreases the egg production resulting in massive economic losses of farmer. The management approaches to minimise the adverse effect of heat stress in poultry production viz., provision of ventilation, density of bird, nutritional manipulation, supplementation of minerals and electrolyte. Controlling the environmental variation is a critical to successful poultry production and welfare.
\end{abstract}

\section{Introduction}

Poultry production is one of the fastest growing sectors of livestock industry in developing countries. Environmental variation is one of the major factors that affect sustainability of livestock production systems in tropical climate (Sinha et al., 2017a). Heat Stress decline production performance and death of chicken results in adversely affects the return from the enterprise. Heat stress has an adverse effect on egg production, egg weight and shell quality of laying hen (Muiruri and Harrison, 1991; Balnave and Muheereza, 1997; Whitehead et al., 1998). Climatic variables like temperature, humidity, radiation and wind speed that directly affect the mechanism of thermoregulation and rates of heat exchange by all animals (NRC, 1981). Heat stress is a major factor that decreases productivity and reproductive efficiency of livestock due to lower feed intake and negative energy balance (De Rensis and Scaramuzzi, 2003). Chronic heat stress had 
lower broiler production due to decline feed digestibility such as proteins, fats, starch (Bonnet et al., 1997). In addition, acute heat stress drastically decreases reproductive performance of hens due to alterations in acid-base balance and ion exchange mechanism (Mahmoud et al., 1996). Increase of temperature will lead to increases etiologic bacteria and parasites around the animals in surrounding environment. Climate change influences the emergence of disease and their transmission due to increases vectors, pathogens.

\section{Sign of heat stress in poultry}

The signs of heat stress in poultry are panting with open mouth, elevated their wings and squatting near to the ground, droopy acting, slowness and lethargic closed eyes, lying down, increased water intake, decreased appetite, drop in egg production, reduced egg size, poor egg shell quality, reduced body weight, and increased cannibalism (Nardone et al., 2010; Dayyani and Bakhtiyari, 2013). Birds are trying to lose heat by gasping and changing the position of their feathers, losing water in their breath and cooling by evaporation through the surface of the lungs. Birds are facing to heat stress conditions, they spend less feeding time during feeding, more time drinking and panting, less time moving or walking and more time resting (Mack et al., 2013).

\section{Effect of heat stress on poultry production}

Heat stress adversely affects the efficiency of broiler production and their meat quality. High environmental temperature and THI value above the critical thresholds level lead to reduced feed intake, lower body weight, and lower feed conversion efficiency (Sohail et al., 2012). Chronic heat exposure adversely affects the meat quality and fat deposition in broilers, but it is breed dependent (Lu et al.,
2007). Exposure of bird to high solar radiation is coupled with depression of chemical composition and meat quality in broilers industry (Dai et al., 2012; Imik et al., 2012). Exposure of high temperature during the growing phase of broilers has been related with poor meat characteristics of broiler chicken and loss their quality (Lu et al., 2007; Zhang et al., 2012). Moreover, exposure of heat stress during transportation of birds from production farms to processing centre has been losses meat quality (Dadgar et al., 2010). Exposure of laying hens to climatic stress also resulted in a significant decrease in egg production and egg quality. Various author reported that reducing egg production in hot weather due to decrease in feed intake, reducing the uptake of available nutrients and decreases digestibility of different components of the diet (Allahverdi et al., 2013; Kirunda et al., 2001; Mashaly et al., 2004). So, egg production is inversely correlated with environmental temperature beyond the critical limit. Allahverdi et al., (2013) reported that laying flock in high temperature shows disturbances in acid-base balance in the blood as result of hyperventilation, the birds gasp there is excessive loss of $\mathrm{CO}_{2}$ gas from their lungs. The lowered amount of $\mathrm{CO}_{2}$ in blood causes the rise in blood $\mathrm{PH}$ which reduces the level of $\mathrm{Ca}^{2+}$ ion in the blood that utilized by the shell gland results poor egg quality (Mahmoud et al., 1996).

\section{Effect of heat stress on reproduction}

Heat stress has a great impact on the reproductive performance and egg quality of birds (Donoghue et al., 1989). High temperature with high relative humidity has more detrimental effect on reproduction of animal. Exposure of White Leghorn hens to high environmental temperature to causes decline in reproductive activity leads to reproductive failure and poor egg quality 
(Ebeid et al., 2012). The reduction in reproductive performance of domestic birds coupled with heat stress due to decrease LH levels and hypothalamic gonadotropinreleasing hormone-I content (Donoghue et al., 1989; Etches et al., 1995). Diminishing reproductive performance of poultry in heat stress due to disturbance the thermoregulatory mechanisms, might be modulated at the level of the hypothalamus and pituitary (El Halawani et al., 1973; Saarela et al., 1977).

\section{Effect of heat stress on behavioral and physiological responses}

Thermoregulation is an important role in maintaining the homeostasis and it is controlled by central, metabolic and endocrine systems. The body mass, confirmation and morphological parameters such as fur color are related to basal metabolic rate, can use of behavioral adjustments (Canals et al., 1989; Cooper et al., 2008). Thermoregulatory capacities of animal play an adaptive role to survive in adverse environment. Under high environmental temperature, birds change their behavioural and physiological responses to maintain their body temperature through seeking thermoregulation. Birds are subjected to under heat stress conditions time spend less in feeding, more in drinking, panting, and wings elevation, move towards cooler surfaces (Mack et al., 2013). In adverse climatic condition, maintaining homeostasis mechanism in birds by heat exchange between environment and air sac through convection, evaporative heat loss, perspiration and vasodilation process (Mustaf et al., 2009; Fedde, 1998).

\section{Effect of heat stress on the immunolgical responses}

Heat stress has negative effects on health status of birds leading to changes in physiology, metabolism, hormonal and immune system. At high temperature decreases synthesis of $\mathrm{T}$ and $\mathrm{B}$ lymphocytes and suppression of phagocytic activity of blood leukocytes (Kadymov and Aleskerov, 1988). Bartlett and Smith (2003) found that lower levels of total circulating antibodies and lower levels of specific $\operatorname{IgM}$ and $\operatorname{IgG}$ in broiler under heat stress. Nathan et al., (1976) reported that decrease total WBC and activities of leukocytes subsequent heat exposure. Zulkifi et al., (2000) also supported that heat stress had significantly decline in antibody production. Inflection of the immune response by the central nervous system (CNS), and is mediated by a complex network of nervous, endocrine and immune systems.

\section{Management approaches to reduce heat stress poultry}

To reduce the heat stress in poultry is the multidisciplinary approach. Modification of surrounding environment, ventilation system, bird density and nutritional management to reduces the heat stress in poultry (Dayyani and Bakhtiyari, 2013).

\section{Modification of surrounding environment}

Environmental temperature and relative humidity of the surrounding environment affects the evaporative cooling mechanism in birds. Evaporative heat loss increases in high temperature with wind speed but decreases with increasing humidity (Lin et al., 2005; Sinha et al., 2017b). The surrounding environment is controlled by using various things such as fans, fogger with fan, cooling pads, curtain, static pressure controllers and thermostats. Provision of intermittent light had positive effect that related to lower heat production in poultry (Ketelaars et al., 1986). The orientation of building, insulation and roof overhang are influence the temperature inside the poultry house. Air movement inside 
the house is important for efficient ventilation. Use of sprinkler and fogger with fan reduces the temperature inside the house on hot climatic condition (Sinha et al., 2018). Environmentally controlled houses used mechanical ventilation systems and air movement is produced by fans and exhaust fan in the building.

\section{Ventilation system}

Good ventilation system is essential for heat stress management. Removes the moisture loaded air from the poultry house and enter equal amount of fresh air from outside. Ventilation system should be maximized as the air movement assist removal of ammonia, moisture and carbon dioxide from the poultry house and enter fresh oxygen from outside (Butcher and Miles, 2012). Proper ventilation houses can provide consistent airflow patterns. Tunnel ventilation connects moving air of building from inlets to exhaust fans, providing high airflow speed. This fast air movement increases convective heat loss, reducing the body temperature of birds. The air velocity of tunnel ventilation is about 350 feet/minute. Evaporative cooling pads works on the same cooling principle as foggers, air is cooled inside the house when it passes through the cooling pads. Circulation fans are recommended for proper ventilation in a good ventilated house for maximizes air movement over the birds to increase convective cooling. The installation of circulation fans at $1-1.5$ metre above the floor and tilted downward about $5^{\circ}$ angle for producing maximum air over the birds (Daghir, 2008).

\section{Nutritional management}

Reduce the heat stress in poultry by nutritional management approaches. Decrease in feed intake and increase water intake of poultry under hot climate to control the body temperature (Gous and Morris, 2005; Sohail et al., 2012). Feed intake will be reduced by $1.2 \%$ for every $1{ }^{\circ} \mathrm{C}$ rise in the temperature range of $22-32^{\circ} \mathrm{C}$ and $5 \%$ for $1{ }^{\circ} \mathrm{C}$ rise in the temperature range of $32-38^{\circ} \mathrm{C}$. Feeding of laying hens during the evening period has been found to improve laying rate and egg shell quality through increased calcium intake. Vitamins and mineral supplementation has been determine to decrease mortality and improve growth performance of poultry birds during heat stress as because heat stress increases excretion of mineral from body and decreases the serum and liver concentrations of vitamins and minerals (Sahin et al., 2009). Addition of fat and reduction of excess fat in poultry ration are recommended to minimise the adverse effect of heat stress (Ghazalah et al., 2008; Rahman et al., 2002). The addition of fat up to $5 \%$ in the diet increases the energy value of feed constituents and decreases the rate of food passage in the GI tract and thus increase nutrient utilization (Mateos et al., 1982; Daghir, 2008). Supplementation of minerals like ammonium chloride $(\mathrm{NH} 4 \mathrm{Cl})$ sodium bicarbonate (NaHCO3), sodium chloride $(\mathrm{NaCl})$, potassium chloride $(\mathrm{KCl})$ and potassium sulphate (K2SO4) in drinking water of poultry are beneficial effect under heat stress condition (Smith and teeter, 1988; Ubosi et al., 2003; Ahmad et al., 2005). Teeter et al., (1985) reported that supplementation of $\mathrm{NH} 4 \mathrm{Cl}$ at 3 and $10 \mathrm{~g} / \mathrm{kg}$ in poultry feed under high environment temperature had improvement in weight gain up to 9.5 and 25 $\%$ respectively. Supplementation of vitamin $\mathrm{C}$ under high temperature is most effective to reducing mortality rate in broiler and laying hens (Njoku, 1986; Ahmed et al., 2005). Vitamin $\mathrm{C}$ acts as antistressor and growth stimulant in commercial broiler production due to maintenance of normal collagen metabolism (Mahmoud et al., 2004; McDonald et al., 1992). Supplementation of vitamin $\mathrm{E}$ during heat stress was beneficial to laying hens, maintain the biological 
membranes because protects cells and tissues from oxidative damage induced by free radicals (Whitehead et al., 1998; Sahin et al., 2001).

\section{Water intake}

At high temperatures, chickens consume more water than feed. The reduced water intake is primarily behind the decrease in production. Water intake of birds increases about $7 \%$ for every $1^{\circ} \mathrm{C}$ increase above $21^{\circ} \mathrm{C}$ (NRC, 1994). Birds performance depends upon water temperature, drinker type, shape and height of water trough under heat stress (May et al., 1997; Daghir, 2009). May et al., (1997) observed that significant decrease in water intake of birds at high ambient temperature from nipple drinkers as compared to bell drinkers.

It is concluded that heat stress adversely affects the commercial poultry production through reduced feed intake and high mortalities. The negative effects of heat stress on broilers and laying hens, reduced growth and egg production to deteriorate egg quality. High environmental temperature increases mortality of poultry due to inhibition of immune responses. Feeding management practices such as changes in energy: protein ratio, wet feeding, feeding time, drinker type and height had improved performance under high environmental temperature.

\section{References}

Ahmad, T., Sarwar, M., Mahr-Un-Nisa, Ahsan-Ul-Haq and Zia-Ul-Hasan, (2005). Influence of varying sources of dietary electrolytes on the performance of broiler reared in a high temperature environment. Animal Feed Sci. and Technol., 20: 277-298.

Ahmed, N., Haldar, S., Pakhira, M.C. and Ghosh, T.K. (2005). Growth performances, nutrient utilization and carcass traits in broiler chickens fed with a normal and a low energy diet supplemented with inorganic chromium and ascorbic acid. J. Agric. Sci., 143: 427-439.

Allahverdi, A., Feizi, A., Takhtfooladi, H.A. and Nikpiran, A. (2013). Effects of Heat Stress on Acid-Base Imbalance, Plasma Calcium Concentration, Egg Production and Egg Quality in Commercial Layers. Global Veterinaria., 10(2): 203-207.

Balnave, D. and Muheereza, S.K. (1997). Improving eggshell quality at high temperatures with dietary sodium bicarbonate. Poult. Sci., 76: 558-593.

Bartlett, J.R. and Smith, M.O. (2003). Effects of different levels of zinc on the performance and immunocompetence of broilers under heat stress. Poult. Sci., 82: 1580-1588.

Bonnet, S., Geraert, P.A. Lessire, M. Carre, B. and Guillaumin, S. (1997). Effect of high ambient temperature on feed digestibility in broilers. Poult. Sci., 76: 857-863

Butcher, G.D. and Miles, R. (2012). Heat stress management in broilers. VM65 series of the Veterinary Medicine Large Animal Clinical Sciences Department, Florida Cooperative Extension Service, Institute of Food and Agricultural Sciences, University of Florida

Canals, M., Rosenmann, M. and Bozinovic, F. (1989). Energetics and geometry of huddling in small mammals. $J$. Theoretical Biology., 141(2): 181-189.

Cooper C.E. and Geiser, F. (2008). The "minimal boundary curve for endothermy" as a predictor of heterothermy in mammals and birds: a review. Journal of Comparative Physiology B-Biochemical Systemic and Environmental Physiology, 178(1), 1-8.

Dadgar, S., Lee, S.S., Leer, T.L., Burlinguette, N., Classen., H.L., Crowe, 
T.G. and Shand, P.J. (2010). Effect of microclimate temperature during transportation of broiler chickens on quality of pectoralis major muscle. Poult. Sci., 89: 1033-1041.

Daghir, N.J. (2008). Broiler feeding and management in hot climates, in: Daghir, N.J. (Ed.) Poultry production in Hot Climate, pp. 227-260 (CAB International. Cromwell Press, Trowbridge)

Daghir, N.J. (2009). Nutritional strategies to reduce heat stress in broilers and broiler breeders. Lohmann information. 44: 615.

Dai, S.F., Gao, F., Xu, X.L., Zhang, W.H., Song, S.X. and Zhou, G.H. (2012). Effects of dietary glutamine and gammaaminobutyric acid on meat colour, $\mathrm{pH}$, composition, and water-holding characteristic in broilers under cyclic heat stress. Br. Poult. Sci., 53: 471-481.

Dayyani, N. and Bakhtiyari, H. (2013). Heat stress in poultry: background and affective factors. International journal of Advanced Biological and Biomedical Research. 1(11): 1409-1413

De Rensis, F. and Scaramuzzi, R.J. (2003). Heat stress and seasonal effects on reproduction in the dairy cow-a review. Theriogenology., 60: 1139e51

Donoghue, D.J., Krueger, B.F. Hargis, B.M. Miller, A.M. and El Halawani, M.E. (1989). Thermal stress reduces serum luteinizing hormone and bioassayable hypothalamic content of luteinizing hormone-releasing hormone in hens. Biol. Reprod., 41: 419-424.

Ebeid, T.A., Suzuki, T. and Sugiyama, T. (2012). High ambient temperature influences eggshell quality and calbindin-D28k localization of eggshell gland and all intestinal segments of laying hens. Poultry Sci., 91: 2282-2287.

El Halawani, M.E., Waibel, P.E., Appel, J.R. and Good, A.L. (1973). Effects of temperature stress on catecholamines and corticosterone of male turkeys. Am. J. Physiol., 224: 384-388.

Etches, R.J., John, T.M. and Gibbins. V.A.M. (1995). Behavioural, physiological, neuroendocrine and molecular responses to heat stress. Pages $31-65$ in Poultry Production in Hot Climates. N. J. Daghir, ed. CAB Int., Wallingford, UK.

Fedde, M.R. (1998). Relationship of structure and function of the avian respiratory system to disease susceptibility. Poult. Sci., 77: 1130-1138.

Ghazalah, A.A., Abb-Elsamee, M.O. and Ali, A.M. (2008). Influence of dietary energy and poultry fat on the response of broiler chicks to heat stress. Int. J. Poult. Sci., 7: 355-359

Gous, R.M. and Morris, T.R. (2005). Nutritional interventions in alleviating the effects of high temperatures in broiler production. World's Poult. Sci. J., 61: 463-475.

Imik, H., Atasever, M.A., Urgar, S., Ozlu, H., Gumus, R. and Atasever, M. (2012). Meat quality of heat stress exposed broilers and effect of protein and vitamin E. Br. Poult. Sci., 53: 689-698.

Kadymov, R.A. and Aleskerov, Z.A. (1988). Immunological reactivity of poultry organism under high temperature conditions. Dokl. Vses. Akad. S-Kh. Nauk Im. V. I. Lenina 5: 33-35

Ketelaars, E.H., Verbrugge, M., Van Der Hel, W., Van De Linden, J.M. and Verstegen, W.M.A. (1986). Effect of intermittent lighting on performance and energy metabolism of broilers. Poultry Sci., 65: 2208-2213.

Kirunda, D.F., Scheideler, S.E. and McKee. S.R. (2001). The efficacy of vitamin $E$ (DL-alpha-tocopheryl acetate) supplementation in hen diets to alleviate egg quality deterioration associated with high temperature exposure. Poult. Sci., 80: 1378-1383. 
Lin, H., Zhang, H.F., Du, R., Gu, X.H., Zhang, Z.Y., Buyse, J. and Decupere, E. (2005). The thermoregulation response of broiler chickens to humidity at different ambient temperatures I. Fourweek-age. Poultry Sci., 84: 1173-1178.

Lu, Q., Wen, J. and Zhang, H. (2007). Effect of chronic heat exposure on fat deposition and meat quality in two genetic types of chicken. Poult. Sci., 86: 1059-1064.

Mack, L.A., Felver-Grant J.N., Dennis, R.L. and Cheng, H.W. (2013). Genetic variation aiter production and behavioral responses following heat stress in 2 strains of laying hens. Poult. Sci., 92: 285-294.

Mahmoud, K.Z., Beck, M.M., Scheider, S.E., Forman, M.F., Anderson, K.P. and Kachman, S.D. (1996). Acute high environmental temperature and calciumestrogen relationship in the hen. Poult. Sci., 75: 1555-1562.

Mahmoud, K.Z., Edens, F.W., Eisen, E.J. and Havenstein, G.B. (2004). Ascorbic acid decreases heat shock protein 70 and plasma corticosterone response in broilers subjected to cyclic heat stress. Comparative Biochemistry and Physiology Part B: Biochem. \& Biology., 137(1): 137-142.

Mashaly, M.M., Hendricks, G.L., Kalama, M.A., Gehad, A.E., Abbas, A.O. and Patterson, P.H. (2004). Effect of heat stress on production parameters and immune responses of commercial laying hens. Poult Sci., 83: 889-894.

Mateos, G.G., Sell, J.L. and Eastwood, J.A. (1982). Rate of food passage as influenced by level of supplemental fat. Poult. Sci., 61: 94-100.

May, J.D., Lott, D.B. and Simmons, J.D. (1997). Water consumption by broilers in high cyclic temperatures: bell versus nipple waterers. Poult. Sci., 76: 944-947.

McDonald, P., Edward, R.A. and Greenholgh,
J.F.D. (1992). Animal Nutrition. Longman Scientific and Tech., New York, USA, Pp- 88.

Muiruri, H.K., and Harrison, P.C. (1991). Effect of roost temperature on performance of chickens in hot ambient environments. Poult. Sci., 70:2253-2258

Mustaf, S., Kahraman, N.S. and Firat, M.Z. (2009). Intermittent partial surface wetting and its effect on body-surface temperatures and egg production of white brown domestic laying hens in Antalya (Turkey). Br. Poult. Sci., 50: 3338.

Nardone, A., Ronchi, B., Lacetera, N., Ranieri, M.S. and Bernabucci, U. (2010). Effects of climate change on animal production and sustainability of livestock systems. Livestock Sci., 130: 5769.

Nathan, D.B., Heller, E.D. and Perek, M. (1976). The effect of short heat stress upon leucocyte count, plasma corticosterone level, plasma and leukocyte ascorbic acid content. $\mathrm{Br}$. Poult. Sci. 17: 481-485.

Njoku, P.C. (1986). Effect of dietary ascorbic acid supplementation on the performance of broiler chickens in a tropical environment. Anim. Feed. Sci. Tech., 16: 17-24.

NRC, (1994). Nutrient requirements of poultry. 9ed National Academy Press, Washington, DC.

NRC. (1981). Effect of environment on nutrient requirements of domestic animals. Committee on Animal Nutrition. Subcommittee on Environmental Stress. National Academy Press, Washington DC.

Rahman, M.S., Pramanik, M.A.S., Basak, B., Tarafdar, S.U. and Biswas, S.K. (2002). Effect of feeding low protein diets on the performance of broilers during hothumid season. Int. J. Poult. Sci., 1: 35-39

Saarela, S., Hissa, R., Hohtola, E. and Jeronen, E. (1977). Effects of -methyl- 
para-tyrosine and temperature stress on monoamine and metabolite level in the pigeon. J. Therm. Biol., 2: 121-126

Sahin, K., Sahin, N., Kucuk, O., Hayirli, A. and Prasad, A.S. (2009). Role of dietary zinc in heat stressed poultry: A review. Poult. Sci., 88: 2176-2183.

Sahin, K., Sahin, N., Onderct, M., Yaralioglu, S. and Kucuk, O. (2001). Protective role of

supplemental vitamin $\mathrm{E}$ on lipid peroxidation, vitamins $\mathrm{E}, \mathrm{A}$. and some mineral concentrations of broilers reared under heat stress. Vet. Med. Czech., 46(5): 140-144.

Sinha R., Kamboj, M.L., Lathwal, S.S., and Ranjan, A. (2018). Effect of housing management on production performance of crossbred cows during hot-humid season. Indian J. Anim. Res., 52 (7): 1091-1094.

Sinha, R., Kamboj M.L., Ranjan, A. and Lathwal, S.S. (2017b). Effect of modified housing on behavioural and physiological responses of crossbred cows in hot humid climate. Indian $J$. Anim. Sci., 87 (10): 1255-1258.

Sinha, R., Lone, S.A., Ranjan, A., Rahim, A., Devi, I and Tiwari, S. (2017a). The impact of climate change on livestock production and reproduction: ameliorative management. International Journal of Livestock Research., 7(6): 18.

Smith, M.O. and Teeter, R.G. (1988). Practical application selection of potassium chloride and fasting during naturally occurring summer heat stress. Poult. Sci., 64: 36.
Sohail, M.U., Hume, M.E., Byrd, J.A., Nisbet, D.J., Ijaz, A., Sohail, A., Shabbir, M.Z. and Rehman, H. (2012). Effect of supplementation of prebiotic mannanoligosaccharides and probiotic mixture on growth performance of broilers subjected to chronic heat stress. Poult. Sci., 91: 2235-2240.

Teeter, R.G., Smith, M.O. and Owens, F.N. (1985). Chronic heat stress and respiratory alkalosis: occurrence and treatment in broiler chickens. Poult. Sci., 64: 1060-1064.

Ubosi, C.O., Otika, A.E. and Diarra, S.S. (2003). Effect of potassium chloride and sodium bicarbonate supplementation on the performance of laying hens in a hot dry environment. Sahel J. Vet. Sci., 2: 23-26.

Whitehead, C.C., Bollengier-Lee, S., Mitchell, M.A. and Williams, P.E.V. (1998). Vitamin E can alleviate the depression in egg production in heat stressed laying hens. In: Proc. Of spring meeting, WPSA-UK Branch Scarborough. Pp. 55-56

Zhang, Z.Y., Jia, G.Q., Zuo, J.J., Zhang, Y., Lei, J., Ren, L. and Feng, D.Y. (2012). Effects of constant and cyclic heat stress on muscle metabolism and meat quality of broiler breast fillet and thigh meat. Poult. Sci., 91: 2931-2937.

Zulkifi, I., Norma, M.T., Israf, D.A. and Omar. A.R. (2000). The effect of early age feed restriction on subsequent response to high environmental temperatures in female broiler chickens. Poult. Sci., 79:1401-1407.

\section{How to cite this article:}

Ashish Ranjan, Ranjana Sinha, Indu Devi, Abdul Rahim and Shiwani Tiwari. 2019. Effect of Heat Stress on Poultry Production and their Managemental Approaches. Int.J.Curr.Microbiol.App.Sci. 8(02): 1548-1555. doi: https://doi.org/10.20546/ijcmas.2019.802.181 